\title{
A “boa imprensa católica" na divulgação das visões acusatórias sobre a maçonaria na década de 1930
}

\author{
The "good catholic press" in the dissemination of accusatory views on masonry in the 1930s
}

\author{
Augusto César Acioly Paz Silva \\ (iD) https://orcid.org/0000-0001-7135-1834 \\ Autarquia de Ensino Superior de Arcoverde/Centro de Ensino Superior de Arcoverde
}

\begin{abstract}
Resumo: Partindo da concepção de Boa Imprensa, que ganhou espaço no cenário intelectual católico nos anos iniciais do século XX, trabalharemos com a análise de dois periódicos produzidos pela Arquidiocese de Olinda e Recife: a Tribuna Religiosa e o Boletim da Arquidiocese, espaços centrais de difusão do ideário católico na década de 1930. O nosso objetivo é apresentar as formas como a maçonaria era representada nesses órgãos de imprensa. A partir de tal perspectiva, observaremos como surgiram as visões e representações negativas que, em muitos momentos, desdobravam-se em versões acusatórias sobre os maçons e a maçonaria. A utilização desse recurso tinha como objetivo demonstrar as supostas estratégias de controle político que seriam utilizadas pela maçonaria - na visão destes órgãos de imprensa - para a criação de uma sociedade orientada pela "falta de fé e ordem". Dessa maneira, destacar o caráter perigoso e nefasto da maçonaria era algo importante a ser exposto pela "boa imprensa". Seguindo a construção de tal cenário, neste procuramos explorar como se estruturou a ação desses espaços de comunicação patrocinados pela Igreja Católica e a atuação dos seus intelectuais, procurando também analisar as formas como a maçonaria era apresentada em tais periódicos, elemento que nos ajuda a compreender o processo de construção e circulação dessas imagens - com forte apelo acusatório - sobre a maçonaria, ao mesmo tempo que ilumina as possibilidades de compreendermos como as visões negativas a respeito da instituição foram forjadas no interior das culturas políticas e históricas da sociedade brasileira.
\end{abstract}

Palavras-chave: Maçonaria. Imprensa católica. Representações.

Abstract: Starting from the conception of Good Press, which gained space in the Catholic intellectual scenery in the early years of the twentieth century, we will work with the analysis of two periodicals produced by the Archdiocese of Olinda and Recife: the Religious Tribune and the Bulletin of the Archdiocese, central spaces for dissemination of the Catholic ideal in the 1930s. Our goal is to present the ways in which Masonry was represented in these press agencies. From this perspective, we will observe how the negative views and representations that, in many moments, unfolded in accusatory versions about Masons and Masonry emerged. The use of this resource aimed to demonstrate the supposed strategies of political control that would be used by Masonry - in the view of these press agencies - for the creation of a society guided by "lack of faith and order". Thus, highlighting the dangerous and nefarious character of Freemasonry was something important to be exposed by the "good press". Following the construction of such a scenery, in this we seek to explore how the action of these communication spaces sponsored by the Catholic Church and the actions of its intellectuals was structured, also seeking to analyze the forms with the a Masonry was presented in such periodicals, an element that helps us to understand the process of construction and circulation of these images - with strong accusatory appeal - on Freemasonry, while illuminating the possibilities of understanding how negative views about the institution were forged within the political and historical cultures of Brazilian society.

Keywords: Freemasonry. Catholic press. Representations.

Esta obra está licenciada sob uma Creative Commons - Atribuição 4.0 Internacional 


\section{O ideal da "boa imprensa" nos jornais pernambucanos}

Na terceira página do jornal $A$ Tribuna Religiosa, no mês de julho de 1935, encontra-se publicada uma nota assinada pelo segundo Cardeal brasileiro, D. Sebastião Leme (1882-1942), que entre os anos de 1916 a 1921 foi arcebispo de Olinda e Recife. Ao longo da década de 1930/1940, o religioso representava um símbolo importante da articulação entre Igreja Católica Romana no Brasil, poder, segmentos políticos e intelectuais que advogavam a influência de tais segmentos no Estado e na sociedade brasileira. Ao apresentar a necessidade de que "todos compreendam a gravíssima obrigação de auxiliar, moral e materialmente, a boa imprensa. Distribuir ao povo um bom jornal é obra mais meritória que dar-Ihe pão e dinheiro" (LEME, 1935, p. 3), o Cardeal Leme reforçava um discurso de defesa e do papel que deveria ser desempenhado pela imprensa católica. Tal ideal não era estranha a sua prática pastoral, uma vez que nas décadas iniciais do século XX ele foi um defensor ardoroso da imprensa como estratégia de defesa e formação de um ambiente sociocultural sintonizado com as concepções e referências intelectuais relacionadas ao ideário católico (NASCIMENTO, 1967, p. 39).

Marcos Gonçalves (2008, p. 63-84) e Jérri Marin (2018, p. 197-217), por meio de suas pesquisas, empreendem reflexões que colaboram no sentido de apresentar como se deu o processo de estruturação de uma imprensa católica que dialogava com o conceito daquilo que se convencionou denominar de boa imprensa. Em ambos os estudos, aliados a todo um conjunto de reflexões historiográficas clássicas, os autores procuram observar o papel da imprensa católica no processo de construção de um jornalismo sintonizado com os seus interesses, apresentando, de maneira clara, os entraves atravessados pela instituição na materialização dos objetivos.

Mesmo assim, com toda uma propaganda de mobilização na adesão à formação de jornais e espaços de comunicação relacionados ao segmento católico no Brasil, é possível - como aponta Gonçalves e Marin - que a adesão do clero brasileiro não foi suficiente para instituir uma imprensa madura, a qual divulgasse as aspirações católicas, colaborando na formação intelectual do laicato, ao mesmo tempo em que impusesse barreiras aos avanços dos "erros modernos" materializados pela inteligência militante católica, espírita, protestante, maçônica e liberal. A discussão a respeito do incentivo e do apoio efetivo, por intermédio da imprensa, ao desenvolvimento e consolidação de um espaço de publicização intelectual católico é um tema recorrente, o qual avança e retrocede, a depender do empenho das lideranças católicas brasileiras.

Ao enfatizar o papel que um periódico católico cumpriria numa cruzada com o objetivo de promover a redenção moral e cultural da sociedade, o cardeal brasileiro formulou o entendimento sob o qual os desafios apresentados pela Igreja Católica brasileira encontravam-se diretamente estabelecidos no sentido da formação de um conjunto de sensibilidades intelectuais junto à população brasileira. Desde o início da República, a hierarquia católica procurou intensificar esse projeto, o qual, após a chegada de Getúlio Vargas ao poder, avançou e resultou numa relação mais estreita entre as lideranças religiosas e o Estado brasileiro.

Nesse sentido, as disputas intelectuais e os contendores da arena haviam se multiplicado. Agora, os alvos da hierarquia eclesiástica católica não eram somente os maçons de viés liberal, mas os comunismos, os socialismos materialistas, os protestantismos e os espiritismos de todos os matizes. Considerados em alguma medida como erros modernos, todos eles eram manipulados num grande complô - contra as forças e raízes católicas brasileiras, aspecto este que, aliás, tornava-se marca da identidade nacional.

Segundo o Cardeal, ao revelar-se qual o lugar que a Tribuna ocupava na qualidade de órgão de imprensa da Arquidiocese de Olinda e Recife, expressava-se o papel desse espaço no seio do laicato e da intelectualidade católica. No testemunho da atuação do periódico em relação à formação das sensibilidades militantes e intelectuais dos fiéis católicos, a Tribuna encontrava-se vinculada ao de representante da "boa imprensa".

Sob tal orientação, o jornal utilizava, como um de seus subtítulos, a vinculação com a 
Associação da Boa Imprensa. Por meio dessa estratégia, procurava-se destacar sua importância e sua adesão ao projeto de construção de uma rede de amplificação do jornalismo inspirado nas qualidades defendidas pela Santa Sé - o de ser um divulgador do ideário e dos princípios culturais do catolicismo. A sua vinculação com a boa imprensa passou a ser explorada a partir do ano de 1923, após um período de crise (entre os anos de 1921 a 1923) no curso do qual o jornal deixou de circular. O uso do termo e a filiação com o ideário da boa imprensa relaciona-se diretamente com a criação da associação, no ano de 1923, pelo arcebispo pernambucano D. Miguel Valverde (19221951). Como destaca Silva (2014), Marin (2018) e Gonçalves (2008), mediante a estruturação dessa entidade, nos meios de comunicação católicos ganhava força - de maneira mais organizada do ponto de vista institucional - a concepção da necessidade de estruturar estratégias de financiamento para subvencionar órgãos de imprensa que pudessem propagandear a reflexão intelectual da hierarquia da arquidiocese de Olinda e Recife.

Ao mesmo tempo, o arcebispo conclamava os fiéis para a importância de cultivar uma imprensa que se esforçasse na divulgação de uma agenda propositiva e de combate às ideias que se apresentavam como corruptoras da moral e dos bons costumes de raiz católico-cristã. A nota publicada pelo Cardeal Leme, na edição de julho de 1935, constituiu-se numa convocação ao engajamento financeiro para que não desaparecessem as boas ideias disseminadas por intermédio da pena dos autores do órgão.

Pensar o caráter qualitativo da expressão "boa imprensa" é problematizar toda uma maneira que a imprensa, produzida por instituições católicas e seus intelectuais, utilizava para se pensar, no sentido de delimitar os seus espaços e significados quando a relacionamos com as demais publicações. Essa compreensão se relaciona diretamente pela perspectiva de que o que seria produzido pela imprensa católica encontrava-se num campo de rigor, seriedade e verdade. Enquanto isso, as publicações não vinculadas a tal visão de mundo eram divulgadas por uma imprensa de má qualidade. Isto se observava, principalmente, se os órgãos de comunicação - os que se encontravam no campo oposto aos vinculados à intelectualidade católica - orientavam-se por concepções liberais ou defendiam propostas sintonizadas com concepções que pregavam tolerância religiosa, mudança social ou, até mesmo, flertassem com um ideário modernizante.

Sob tal perspectiva, podemos compreender o conceito de boa imprensa à luz do ideário da sociedade que deveria ser recatolizada. Assim sendo, o cultivo de uma imprensa inspirada no ideal da bondade estabelecia visão e ações profiláticas, ou seja, de prevenção com relação aos conteúdos e ideias que seriam explorados nos periódicos que coadunavam com a proposição em debate. As lógicas defendidas pela Tribuna e pelo Boletim Arquidiocesano, órgãos de imprensa que analisaremos neste artigo, fundiam-se, pois as publicações preocupavam-se com o exercício e a prática de um combate intelectual, tendo como foco os "erros modernos". Dentre eles, destaca-se o maçonismo. A partir da análise de como pensaremos os debates estabelecidos por esta imprensa católica pernambucana, a qual reverberava muitos dos temas nacionais, no tópico seguinte procuraremos pensar como tais confrontos intelectuais e formas de representar a maçonaria circulavam num dos seus principais periódicos: a Tribuna.

\section{A maçonaria, moral maçônica e ensino laico nas páginas da Tribuna}

Inspirados pelas pesquisas efetuadas no jornal a Tribuna, foi possível identificar quais foram as estratégias utilizadas pela publicação no sentido de efetuar, concretamente, o ideal da "boa imprensa". Com efeito, a linha editorial do semanário católico desdobrava-se a fim de formular um conjunto de visões atinentes à maçonaria, visões essas que contribuíram para a formulação de uma representação a respeito da instituição sob uma perspectiva que enfatizava o caráter nocivo e desagregador. Tais aspectos foram eleitos como motes centrais na composição dos discursos, práticas e imagens relativas a essa instituição. De modo que a visão da associação dos "pedreiros 
livres"1 unia-se a um conjunto de forças contrárias ao cristianismo de raiz católico - o qual, no modo de enxergar dos seus intelectuais e do clero, possuía como um dos objetivos centrais a desagregação de um modelo de moral - que se encontrava ligado ao ideário conservador tradicional.

Num artigo, publicado no semanário a Tribuna - datado do dia 24 de janeiro de 1934 -, é possível encontrarmos um dos exemplos concretos da acusação de que as forças ligadas ao catolicismo apresentavam contra a moral duvidosa. O assunto do texto era a "moral maçônica". A narrativa construída ao longo do artigo relatava o processo de organização do Congresso da liga pró-Estado laico e destacava participação ativa de várias lideranças, dentre elas a do grão-mestre da maçonaria local. Nas palavras do autor do artigo, o ponto central das discussões ocasionadas pelo encontro foi a apresentação das "elevadas finalidades morais da escola leiga" (sem autor, 1934, p. 2).

Com uma forte carga de ironia, o articulista ponderava quais seriam as tão elevadas finalidades, as quais, em outras palavras, traduziam-se única e exclusivamente na promoção do ensino laico. Sob esse prisma, o redator do texto procurou demonstrar que por trás da preocupação com a educação, na verdade, eles agiam de maneira sorrateira, na intenção de propor um ensino no qual os valores religiosos deveriam ser duramente repreendidos e perseguidos. Exemplificando a forma de atuação dos maçons, o artigo veiculava como referência textos do jornal francês $L a$ croix, com o objetivo de descrever as estratégias similares de atuação da maçonaria brasileira e pernambucana sob a lógica mundial. É possível identificar qual o objetivo da estratégia encampada pelo periódico católico: reproduzir alguns artigos que diziam respeito à posição maçônica em relação a questões morais, proporcionando, assim, uma visão que provocasse questionamentos sobre as verdadeiras aspirações da instituição. Para reforçar a visão negativa a respeito da maçonaria, o articulista da Tribuna reproduzia as notícias demonstrando quais seriam os fins morais da instituição, como é possível acompanhar a seguir:

O pudor é uma invenção moderna, filha do desprezo que os cristãos tem da forma e da matéria [...] De acordo com semelhante teoria, um conselheiro municipal de Paris, tripingado graduado, ousava dizer: "Queremos arrancar ás meninas e moças o sentimento sagrado do pudor". [...] E um irmão Hubbarb, traduzindo na pratica esse belo programa <<moral >> maçônica, dava na sua escola extranhos conselhos ás meninas suas alunas. (sem autor, 1934, p. 2)

Utilizando a publicação francesa como voz autorizada para demonstrar os objetivos da Maçonaria, o artigo da Tribuna expunha, de maneira clara, qual eram os reais fins maçônicos que, na visão do periódico, seriam antes corruptores do que preocupados com a elevação e a defesa dos bons costumes. O ambiente no qual se desenrolava a história era uma escola. Ao destacar tal espaço, o objetivo do articulista da Tribuna era hastear sobre o ensino laico uma bandeira maçônica, ao mesmo tempo que buscava questionar o significado dessa concepção, colaborando com a estruturação de uma visão negativa a respeito do ideário. Nesse sentido, ao revelar tal proposição, os intelectuais ligados à Tribuna aproveitavam para reforçar e chamar a atenção das famílias no sentido de que os elevados preceitos morais defendidos pela maçonaria eram, na verdade, corruptores da alma e dos instintos femininos, agindo - como podemos observar na narrativa tecida pelo autor do semanário católico - numa perspectiva que reforçava a má-fé.

Claudia Save (1934, p. 3), colaboradora da Tribuna, posicionava-se a favor de um discurso que propunha uma contraposição à provocação promovida por um periódico maçônico do Recife. Aliás, por intermédio do artigo "Os padres não trabalham", a autora procurou desconstruir os argumentos fornecidos pela folha maçônica, orientando sua argumentação no sentido de destacar as estratégias empreendidas pelos redatores maçons, que, nos seus órgãos de imprensa, não

\footnotetext{
${ }^{1} \mathrm{O}$ termo pedreiros livres é sinônimo de maçom. Uma vez que a Maçonaria moderna se encontra historicamente relacionada às confrarias de construção/pedreiros, que possuíam carta de franquias para exercerem suas atividades sem autorização prévia dos poderes constituídos no mundo feudal europeu.
}

SÆCULUM - Revista de História [v. 26, n. 44]. João Pessoa, p. 106-118, jan./jun. 2021, ISSNe 2317-6725 
apresentavam a verdade sobre como atuavam os clérigos brasileiros. Ao assumir a posição de defesa dos religiosos católicos, a colaboradora da Tribuna refutava um conjunto de ideias apresentadas pelo órgão maçônico de comunicação. As palavras utilizadas pela autora do texto eram, em muitos momentos, extremamente fortes quando ela referia-se aos colaboradores da imprensa maçônica. Entre os termos usados, Save rotulou de "imbecis" os argumentos do autor do artigo, que destacava a pouca afeição ao trabalho que os padres católicos, segundo a folha maçônica, experimentavam.

Procurando contrastar tais impressões, Claudia Save reconstrói a imagem dos padres, utilizando para tal um discurso que descrevia as atividades clericais a partir de um conjunto de representações que destacavam as características relacionadas a valores como heroísmo e bravura. Tais argumentos procuravam criar uma imagem que apontava as ações dos religiosos como responsáveis por um processo civilizador, no qual os padres, muitas vezes inspirados por um espírito de abnegação, realizavam obras que, em vez de os colocarem no campo do ócio improdutivo, faziam com que tivessem um vasto conjunto de atividades a desempenhar.

Após ter feito essa explanação inicial, a autora constrói sua argumentação a partir de um conjunto de questionamentos sobre as reais ações maçônicas, colocando em xeque a sua atuação filantrópica e educacional. $\mathrm{O}$ emprego desse procedimento circunscreve-se na realidade enquanto recurso do ideário maçônico: o artifício da dúvida. Deixando para os leitores a visão de que por trás de todo o "bonito" discurso maçônico pairava, na verdade, desconfiança e dissimulação quanto a suas obras, construía-se a visão de que, ipso facto, havia mais propaganda dos maçons do que obras concretas.

Ao trazer à tona certo sentimento de desconfiança, Claudia Save questionava onde estariam os "colégios, hospitais, lazaretos e orfanatos" patrocinados pelos maçons, tão divulgados por eles como sendo parte da sua obra humanitária e filantrópica. A autora interrogava, em tom de desconfiança, a existência concreta dessas ações e de suas finalidades. Tal posição apresentavase como uma estratégia utilizada pela autora com objetivos muito bem definidos. Um dos quais, pois, era criar uma aura de dúvida sobre as "verdadeiras práticas" que, segundo ela, eram largamente propagandeadas pelos "filhos da viúva". ${ }^{2}$

Como exemplo desse ferrenho questionamento da autora, podemos encontrar no seu texto, enquanto recurso estilístico e discursivo, uma preocupação de mesclar aos seus argumentos o elemento da dúvida, junto a uma crítica contundente sobre os elementos e ideias defendidas pela maçonaria. Desse modo, Claudia Save observa:

Ela que apregoa o comodismo da vida religiosa, esquecer-se-á que á sociedade do mistério devemos, em germem, a expulsão dos jesuítas em Portugal, a perseguição católica no México, os distúrbios contra a nossa fé, a Revolução Francêsa, a prisão do nosso D. Vital, para citar exemplos mais conhecidos e próximos? Dize-me: os que te perseguem tem eles uma vida ilibada e irrepreensível? São os que querem o divorcio e a escola leiga, a descristianização da sociedade, a morte de tudo o que pleitêas, são eles felizes, retos e puros? (SAVE, Tribuna Religiosa, 1934, p.3)

Elencando as principais obras maçônicas, a autora lançava luzes sobre os movimentos que ao longo da história teriam sofrido com as ações promovidas pela instituição. Tentando demonstrar qual seria a verdadeira obra maçônica a partir da sua exposição, Claudia Save pretendia apresentar qual era a obra humanitária patrocinada pelos maçons, que na sua avaliação era o incentivo a revoluções, perseguições a religiosos e defesa de bandeiras como divórcio e escola laica, ideias que, na visão da autora, promoviam o desaparecimento de uma sociedade na qual estariam na base da sua formação os princípios cristãos (subentenda-se católicos).

Como é possível acompanhar nas matérias veiculadas, a partir dos periódicos apresentados,

\footnotetext{
${ }^{2}$ Expressão que muitos órgãos da imprensa católica usavam para fazer menção aos maçons, sempre com um ar de ironia.
}

SÆECULUM - Revista de História [v. 26, n. 44]. João Pessoa, p. 106-118, jan./jun. 2021, ISSNe 2317-6725 
as imagens veiculadas colaboravam de maneira intensa no processo de construção de um conjunto de representações, que tanto na Tribuna quanto no boletim arquidiocesano, periódico que analisaremos na próxima seção deste artigo, são pródigos em desenhar a maçonaria dentro de um conjunto de representações nas quais, eram abordados o caráter nefasto e manipulador. Na maioria das situações o local desagregador, encontrava-se na arena política, espaço que na prática, tanto a Igreja Católica quanto a Maçonaria disputavam espaços relacionado à questão da educação e da defesa de comportamentos sintonizados com ideário da liberdade religiosa, dimensão compreendida pela intelectualidade católica como um campo importante de enfrentamento (CHARTIER, 1990; OLIVEIRA, 2017; SILVA, 2020).

Essa denúncia, exposta na Tribuna, representava um impasse que encontraríamos com reincidência nas folhas do semanário católico quando se referia às ações maçônicas. Outro exemplo, que tinha como finalidade revelar os verdadeiros planos acalentados por esta instituição, podemos encontrar na edição do dia 16 de maio de 1934. Nela, divulgando um artigo encontrado no periódico francês Eco de Paris, a Tribuna detalhava informações a respeito das atitudes da Maçonaria francesa, que havia proibido a divulgação do nome dos seus membros (Sem autor, Tribuna Religiosa, 1934, p. 3).

Segundo a matéria encontrada no periódico francês e analisada pela Tribuna, a atitude de não informar a identidade dos maçons franceses, tomada pela Maçonaria daquele país, tinha como objetivo fazer com que a maçonaria pudesse agir mais livremente junto ao senado francês, influenciando resoluções que beneficiassem o ideário defendido por aquela sociedade. Ao levantar tais questões, a Tribuna pretendia lançar luzes sobre as "verdadeiras" ações maçônicas. Já ao dar publicidade sobre esse caso da maçonaria francesa, o semanário católico pernambucano tinha um objetivo central: revelar as estratégias empregadas pela sociedade francesa na sua sede em conquistar e influenciar o poder.

Ao relatar em detalhes o caso noticiado pelo Eco de Paris, a Tribuna acreditava ser de interesse público o conhecimento de tais artimanhas como forma de prevenir à sociedade pernambucana e brasileira a respeito do real caráter da instituição, muitas vezes apresentada como ardilosa. Outro aspecto que se associava à divulgação dessas imagens residia no fato de procurar desconstruir a imagem de que os maçons pernambucanos e brasileiros eram diferentes dos franceses. Ao combater semelhante visão, o periódico católico evidenciava o caráter universal da instituição que, por tais particularidades, tinha os mesmos objetivos em qualquer lugar do mundo, como estratégia para ludibriar e conseguir alcançar os seus reais objetivos.

Podemos também observar no artigo a preocupação em demonstrar a nação francesa enquanto espaço onde os maçons agiam livremente, sem fiscalização dos poderes constituídos. Pois, na perspectiva adotada pelo periódico, grande parte deles estava de alguma maneira a serviço da obra maçônica. Ao reproduzir tal cenário, e tendo a França como exemplo mais frequente, o que se pretendia era instalar uma posição de advertência a partir da qual as imagens da maçonaria teriam força e agiriam livremente, além de ficarem evidentes na memória dos leitores do periódico. ${ }^{3}$

Se na França a maçonaria continuava a desfrutar de prestígio, no interior do mundo político, a Tribuna não deixou também de noticiar o outro lado da moeda, que seria a crise atravessada pela

\footnotetext{
${ }^{3}$ A utilização da França enquanto centro difusor do maçonismo radical sempre foi uma tônica, tanto na literatura e na imprensa antimaçônicas quanto nos intelectuais católicos, que produziam e divulgavam grande parte desse ideário. Ela tinha como um dos seus subprodutos o discurso do complô maçônico que, no imaginário e na Cultura Política francesa, bem como em todo o Ocidente, foi largamente apropriado e divulgado. Ainda no século XVIII, através das narrativas produzidas pelos abades Barruel e François Lefranc, temos de certa forma a instituição dessa visão no interior da cultura política ocidental. Para observamos um pouco a respeito dessa discussão, ver: BARATA, Alexandre Mansur. Maçonaria, Sociabilidade Ilustrada e Independência do Brasil (1790-1822). 1. ed. São Paulo-Juiz de Fora: Annablume-EDUFJF-FAPESP, 2006, p. 198-208; LEFRANC, François. O Véo Levantado, ou o Maçonismo Desmascarado; isto he: o Ímpio e execrando systema dos Pedreiros-Livres conspirados contra a Religião Catholica, e contra o Throno dos Soberanos. Tradução do francês. Lisboa: Imp. Liberal, 1822-23; BARRUEL, Augustin. Memoires pour servir a l'histoire du Jacobinisme, vol. 4. London: De l'Imprimerie Françoise, 1798.
} 
instituição em outros locais do mundo. O uso de tal matéria aparecia como forma de validação de que os argumentos defendidos pelos que analisavam criticamente a maçonaria se confirmavam, uma vez que a derrocada de tal influência parecia como a materialização de que foram compreendidos os verdadeiros malefícios causados pelos maçons ao redor do mundo. Na visão apresentada pelo artigo, porém, a maçonaria representava um perigo, principalmente para a segurança e a ordem pública das nações, exatamente pelo fato de ser "uma associação que faz do segredo a alma de sua vida e que sob segredo, poder cometer todos e quaisquer atos" (sem autor, 1934, p. 4).

Na referência acima, encontramos novamente a ênfase no segredo enquanto categoria para pensarmos a maçonaria como uma instituição que não deveria merecer confiança por parte da sociedade. Tal mote de alguma maneira foi utilizado em muitos momentos das relações entre maçonaria, sociedade e poder do Estado. Através desses usos é possível compreendermos que as visões que tinha como lugares-comuns o perigo, o caráter maléfico de suas ações e a preocupação com a conquista do poder seriam elementos históricos que sofreriam reatualizações. No caso do Brasil, é possível observarmos uma mudança de avaliação a respeito dos reais objetivos da maçonaria a partir da chamada Questão Religiosa. Tal evento, de alguma forma, intensificou o antimaçonismo que constrói sobre a maçonaria um caráter de suspeição (VIEIRA, 1980; PEREIRA, 1986; PEREIRA, 1982; GIRARDET, 1987; BENIMELLI, 1982).

O sentimento de antimaçonismo, que foi amplificado pelo impacto provocado pela Questão religiosa, colaborou num processo que se constituiu na reorganização da Igreja Católica no Brasil, que foi intensificado, a partir da proclamação da República e a separação do Estado. Tais movimentos colaboraram de forma importante, no processo de reestruturação da Igreja Católica brasileira, do ponto de vista institucional e preparou assim, o terreno na transição do século XIX ao $\mathrm{XX}$, fomentando o surgimento e fortalecimento de uma inteligência católica militante, responsável pela fundação de uma imprensa combativa aos erros modernos, dentre os quais, encontrava-se a maçonaria. Além desta ação no campo da imprensa, é possível relacionarmos o impacto da Questão religiosa, dentro de um recorte de maior duração, ensejando o aparecimento de lideranças como Jackson de Figueiredo e outras, que colaboraram na constituição do Centro Dom Vital e de outras associações que procuravam espelhadas no martírio do bispo de Olinda, revigorar o catolicismo nacional, fornecendo a ele, um conjunto de intelectuais, além de um revigoramento popular preocupado em assumir um tom combativo, contra os supostos "inimigos" da fé católica, sejam maçons, protestantes, espíritas e adeptos das religiões afrodescentes ou mesmo, de outras matrizes (SILVA, 2009; SILVA, 2010).

Porém, os dias em que a maçonaria conseguiria livrar-se das denúncias que vários dos seus opositores haviam realizado pareciam, segundo o artigo, estar chegando cada vez mais ao fim. A certeza disso residia na existência de algumas ações concretas que acabavam com a independência e o poder da maçonaria. Os exemplos utilizados para demonstrar o processo de decadência maçônica eram os da Itália, Portugal e Alemanha, países que à época estavam sob a influência de regimes autoritários e totalitários.

Dando continuidade à lista dos exemplos que deveriam ser seguidos, o texto informava ainda que, mesmo em nações como Suíça e França, onde os "pedreiros livres" gozavam de liberdade e influência, existia um processo gradativo de perda de espaço e poder por parte da instituição. Mesmo com toda a realidade contrária à propaganda maçônica, conforme observado por Pierre Dominique - intelectual que, segundo a Tribuna, desfrutava de fortes vínculos maçônicos -, o redator do texto compreendia como exagero a propagação da ideia de um possível desaparecimento político da maçonaria, mesmo com os vários exemplos por ele alistados pela diminuição da sua área de influência.

Podemos observar que um exemplo recorrente nesse contexto, e que tomou conta de outros periódicos, foi o da proibição das atividades maçônicas portuguesas durante o governo salazarista. 
A postura adotada por Portugal foi saudada por grande parte da imprensa católica, representando um dos mais fortes dissabores atravessados pelos maçons na Europa. A fama que tal caso desfrutou junto à imprensa tinha contornos bem definidos, que passavam pela escolha desse exemplo simbolizado pela proibição das atividades maçônicas em Portugal. Logo, em pouco tempo esse país tornou-se modelo concreto de que seria possível combater a maçonaria.

Tamanha polêmica e os detalhes do evento foram examinados, de maneira detalhada, pelo Boletim da Arquidiocese, por meio da publicação que abriu o ano de 1935, demonstrando o processo e os desdobramentos promovidos pela atitude de Salazar em interditar as ações maçônicas em solo português. Esse ponto de vista será discutido de modo mais detalhado no tópico seguinte, no qual tentamos inclusive observar as implicações que tal notícia $A$ situação da maçonaria portuguesa foi um dos temas que abriu as páginas do órgão de imprensa, editado pela Arquidiocese de Olinda e Recife, nos meses de janeiro e fevereiro de 1935. Nessas páginas, relatavam-se as ações promovidas pelo parlamentar português José Cabral durante a sessão de abertura da assembleia, ao longo da qual ele expôs o projeto de fechamento das associações secretas daquele país, e que tinha como um dos principais alvos, na visão do periódico, as ações da maçonaria.

A perseguição a essa instituição pode ser compreendida sob o contexto de combate ao ideário liberal na Europa, que teve como um dos desdobramentos a composição de regimes autoritários, como no caso português do salazarismo, que é um sistema ditatorial no qual o alto grau de vigilância empreendido pelo estado acaba por desconfiar de todas as instâncias, principalmente as que tinham como forma de organização o caráter secreto ou iniciático, como é o caso da maçonaria.

Mesmo contando com a aprovação da maior parte da assembleia portuguesa, o deputado José Cabral encontrou vozes dissonantes ao seu projeto de lei. Uma delas era a do poeta português Fernando Pessoa, que, através do artigo publicado no Diário de Lisboa, realizava uma análise da proposta apresentada pelo parlamentar. Avaliando a proposta como um ato de censura digna do tribunal da Inquisição, Fernando Pessoa, em seu artigo, discorre sobre a maçonaria, desconstruindo muitos dos argumentos usados pelo deputado e que serviriam de base para as suas especulações de culpabilidade da organização. Por meio de uma visão pró-maçônica, o poeta português destaca a sua importância institucional, além de mostrar a total falta de conhecimento do parlamentar sobre a maçonaria.

Fernando Pessoa assim se reporta:

Não faço, creio, ofensa ao sr. José Cabral em supor que, como a maioria dos antimaçons, o autor deste projeto é totalmente desconhecedor do assunto Maçonaria. O que sabe dele é até, porventura, pior que nada, pois naturalmente terá nutrido o seu antimaçonismo da leitura da imprensa chamada católica, onde, até nas coisas mais elementares na matéria, erros se acumulam sobre erros, e aos erros se junta, com a má- vontade, a mentira e a calunia, senhoras suas filhas. (PESSOA, 2006, p. 45-68).

Os argumentos expostos por Pessoa, ao reportar-se às especulações elaboradas pelo deputado, encontram-se entre a ironia e a crítica velada aos que, não tendo entendimento profundo sobre a maçonaria enquanto fenômeno histórico, social e político, prestavam-se às construções mais absurdas a respeito de suas ações. Mesmo realizando uma defesa lúcida da importância e do legado da instituição, o poeta português parece que foi uma voz dissonante frente ao ideário autoritário e ditatorial que tomou conta da sociedade portuguesa, e incentivou a formação de um sentimento de vigilância antimaçônica que tomou conta de vários setores da sociedade, acabando por gerar posições de intolerância em relação a esses setores.

Como já destacamos anteriormente, o Boletim Arquidiocesano foi o principal veiculador das notícias sobre o fechamento das lojas maçônicas portuguesas. Ao longo de mais de seis páginas, a publicação católica tinha como preocupação demonstrar a verdadeira face dessa sociedade. Os 
discursos apresentados nos artigos que ganhavam espaço nas páginas do periódico católico tinham um forte viés antimaçom. Não podemos esquecer que o órgão tecia discurso de um lugar estabelecido socialmente, que era ligado ao ideário católico e representava, então, a voz autorizada dos intelectuais dessa instituição. Inclusive o silêncio e o interdito, muitas vezes observados no texto, merecem ser analisados a partir do contexto e do lugar social de quem produzia o periódico, contribuindo para que possamos compreender melhor, enquanto fonte histórica, qual o lugar ocupado pela publicação.

Abrindo a série de artigos, encontramos A Maçonaria e o Estado Português (Tribuna Religiosa, 1935, p. 6). Nele deparamos com a reprodução da decisão, encampada pelo deputado José Cabral, de levar à assembleia do país uma proposta de combate às associações secretas, tendo como alvo principal a maçonaria. Dentro do seu campo discursivo, o autor do projeto justifica a elaboração dessa proposta inspirada por ideais nacionais, não sendo seu interesse perseguir nenhuma instituição. Sob esse ângulo, podemos observar uma contradição nos argumentos que ele utiliza, pois, mesmo endossando o seu interesse em perseguir especificamente a Maçonaria, acaba possibilitando que isso aconteça.

Podemos observar tal posição recorrendo ao que o deputado lusitano deixou expresso nos seus argumentos, mais especificamente no discurso da sessão de abertura da assembleia legislativa portuguesa, que foi reproduzido pelo Boletim da Arquidiocese de Olinda e Recife:

Senhores deputados realmente a maçonaria proclama sempre quando as suas palavras se dirigem ao mundo profano, isto é, quando pretende influir no publico nos não temos objetivo político na nossa ação. Entretanto, numa mensagem que o grão-mestre da maçonaria portuguesa, General José Emeno Zibeiro Norton de Matos dirigiu em trinta e um, a grande dieta maçônica, isto é ao povo maçônico, dizia-se coisa que é interessante que vossas excelências conheçam. (sem autor, 1935, p.7).

O tom empregado pelo parlamentar traz como um dos elementos de destaque a preocupação em desvendar os objetivos da maçonaria. Podemos observar o emprego desse tom ao vermos que, segundo o deputado português, a maçonaria, do ponto de vista discursivo, atua com duas lógicas por ele endossadas. Seriam elas: a forma como a instituição se reporta ao mundo qualificado como profano, ou seja, exterior à sua ordem ritualística, onde ela assume não ter nenhum fim político; e, do outro lado, a mensagem comentada por José Cabral, grão-mestre da maçonaria portuguesa, no ano de 1931, em que deixava expressa quais deveriam ser as posições da maçonaria frente ao Estado português.

As palavras do grão-mestre português foram reproduzidas no dossiê escrito pelo mensário católico da arquidiocese, que tinha como fonte os discursos proferidos pelo parlamentar português. Numa clara tentativa de demonstrar que, ao invés do que afirmavam os maçons portugueses, havia sim preocupações de fundo político, utilizou-se o pronunciamento do líder maçom. Na composição da notícia, o órgão de imprensa católico endossava as passagens mais fortes do discurso do grãomestre, o que construía - sobre a fala do deputado e a lógica que o Boletim pretendia formular um discurso ou linguagem autorizada, com classifica Pierre Bourdieu (in ORTIZ, 1983, vol. 39, p. 156-163). Tal perspectiva colabora para que possamos compreender que as ideias que circulavam nos artigos constituíam-se referências do que significava a verdade, pois ao falar sobre a maçonaria e as suas reais intenções, o Boletim Arquidiocesano e até mesmo a Tribuna, periódico que analisamos no tópico anterior, reforçavam a compreensão de que os seus discursos se encontravam num lugar em que as mensagens veiculadas representavam, do ponto de vista discursivo e imagético, o autêntico e o real.

O desdobramento dessa categoria tornou-se visível em outros trechos do dossiê formulado pelo Boletim católico, e pode ser compreendido como uma chave de análise para entendermos quais os seus objetivos ao reproduzirem tais notícias, que se estruturam sob a intenção de formular uma visão a respeito da maçonaria pautada numa posição na qual a desconfiança e o temor seriam 
sentimentos que deveriam ser preservados e disseminados, para que a "máscara real" da instituição fosse apresentada.

Ademais, tendo o legado nocivo da maçonaria portuguesa como centro, o Boletim Arquidiocesano reproduzia mais um artigo do dossiê encontrado na publicação do bimestre janeiro e fevereiro do ano de 1935. Ao analisarmos o texto em questão, cujo título do artigo era A maçonaria e a luta antirreligiosa (1935, p. 9), é possível percebermos que uma das naturezas maçônicas seria a de empreender um combate diuturno com a religião, mesmo que tal conceito fosse identificado como sinônimo de catolicismo, aspecto que já destacamos em outras partes do texto. O conteúdo do boletim remontava ao ano de 1903, destacando as posições que se encontravam, segundo o artigo, num guia maçônico editado naquele ano. No guia, o catolicismo era acusado de incentivar a conspiração universal contra a liberdade dos povos. Ao fornecer publicidade sobre este documento maçônico, o órgão arquidiocesano procurou estabelecer que o combate ao pensamento e práticas religiosas era uma posição oficial da maçonaria, pois, através dessa estratégia, procurava-se demonstrar as intenções maçônicas, rechaçando os argumentos de que os perseguidores eram a Igreja e os seus representantes, quando na verdade tal combate partia dos maçons.

É claro que latente ao foco narrativo e discursivo - fornecido pelas várias partes em que se divide a série de documentos veiculados no Boletim Arquidiocesano - podemos perceber as estratégias que a elite intelectual religiosa pretendia forjar com a publicação das matérias. O objetivo expresso da publicação centrava-se no recurso de que fosse possível formular um exemplo que justificasse, ou "abrisse os olhos dos maçons de boa fé" e dos representantes de governos, para que observassem com cuidado as ações e a maneira pelas quais a maçonaria portava-se na sociedade.

Entre as várias imagens dos textos do mensário católico, as quais compunham o arsenal imagético e discursivo a respeito da maçonaria, se olharmos em larga escala podemos elencar pelo menos dois elementos que são recorrentes no discurso antimaçom. O primeiro deles trabalha na perspectiva de que a maçonaria, camuflada em seu "véu de segredo", detinha grande influência e poder político junto ao Estado. No conjunto dos textos publicados pelo Boletim, extraídos do discurso proferido pelo deputado português, a maior parte versa sobre as estratégias da maçonaria lusitana e suas recomendações no sentido de estar próxima ou, de alguma maneira, influenciando pessoas de destaque no alto escalão do Estado português.

Outro ponto de vista que torna a aparecer nos discursos que analisamos é o que apresenta a maçonaria enquanto instituição contrária à religião, combatendo mais incisivamente o catolicismo. No discurso produzido pelo órgão de imprensa católico, a maçonaria tinha como princípio norteador o estabelecimento de uma campanha vigorosa contra o ideário religioso católico. Tal dimensão pode ser observada, conforme a visão do Boletim, na luta maçônica por um Estado laico, que compreendia a laicidade como sinônimo de que no seio de tal sociedade a religião não teria vez (Boletim Arquidiocesano, 1935, p. 9).

O caso da interdição da maçonaria portuguesa, que ganhou as páginas do Boletim Arquidiocesano nos meses iniciais do ano de 1935, pode ser compreendido a partir do esforço empreendido pela intelectualidade católica de Pernambuco e que se encontrava associada ao ideário nacional, de que o combate ao ideário liberal e laicista constituía-se em tarefa de primeira ordem, no combate às dissoluções morais e do sentimento verdadeiro de nossa população. Trazer um caso externo à realidade vivenciada na região onde a notícia era veiculada consistia numa estratégia largamente utilizada pela imprensa católica, que, por meio da publicidade de casos que envolviam a maçonaria em outras nações, procurava reafirmar o caráter perigoso desta instituição, mesmo que os usos de tais imagens construíssem uma visão homogeneizadora da instituição, que colaborava para empobrecer e estereotipar a Maçonaria. Assim sendo, semelhante estratégia colaborava para que a circulação das visões sobre a maçonaria fosse manipulada e disseminada a partir de um viés reforçado pela noção de perigo e cuidado. 
Tal característica acabava levantando outras suspeitas sobre os procedimentos maçônicos, o de que estariam a serviço de um ideário político de fundo internacionalista, que pretendiam construir o domínio nacional e desarticular as forças políticas verdadeiras e que se preocupavam com a ordem. $\mathrm{O}$ antimaçonismo, na qualidade de força política, foi um capital simbólico importante para que a intelectualidade católica construísse a sua identidade afiançada na lógica da defesa da moral, dos bons costumes, da ordem e preocupação com a população pernambucana e brasileira, frente a uma instituição que não representava o respeito à sociedade brasileira e que se utilizava de um discurso atravessado pela dissimulação, o que do ponto de vista discursivo estruturava uma lógica da suspeita, sobre os maçons e as suas ações (SILVA, 2002).

Esses são temas possíveis de serem observados nas leituras que realizamos tanto do Boletim Arquidiocesano quanto da Tribuna Religiosa e que referendam à imagem de uma maçonaria que deveria além de combatida, ser diuturnamente vigiada pelos poderes constituídos pelo Estado que se portavam sempre a espera de alguma maquinação para desestabilizar uma suposta lógica de ordem defendidas por estes segmentos identificados com a intelligentsia católica.

\section{Considerações finais}

A imprensa católica da década de 1930, principalmente a vinculada ao ideal da Boa imprensa, consistiu como foi possível acompanhar ao longo do texto, num espaço profícuo de difusão e circulação de um conjunto de crenças e posturas que deveriam servir como imagem para os católicos brasileiros e pernambucanos seguirem e defenderem. Através dos artigos que foram veiculados pelos órgãos analisados neste artigo, podemos compreender como tais mecanismos foram utilizados seguindo a lógica discursiva, que visava conceber a visão de que esses órgãos de imprensa eram veiculadores da verdade em contraposição às informações desqualificadas produzidas pelos maçons.

Seguindo tais proposições, é possível compreender que as publicações tiveram papel fundamental na formulação das sensibilidades e da visão sobre a maçonaria em Pernambuco, pois, além de prestar-se a desenvolver suas atividades no campo da imprensa na defesa de ideias e visões de mundo, elas também se converteram em campos de batalha contra os maçons e os ideais que eles representavam na sociedade. Por essa razão, acreditamos que empreender uma reflexão sobre esses elementos - abrindo margem para pensarmos a ação dos meios de comunicação e o imaginário político, social e cultural que eles formularam - torna-se uma abordagem determinante no sentido de compreendermos quais as suas raízes e as formas como a maçonaria foi sendo representada nesses periódicos e na história da instituição ao longo do século XX (SILVA, 2013; ANECCHINI, 2020).

\section{Fontes}

Sem autor. Moral Maçônica. A Tribuna. Recife, 24 de janeiro de 1934. p. 2

SAVE, Claudia. Dize-me, quem te persegue sacerdote?. A Tribuna. Recife, 10 de fevereiro de 1934, p. 3.

Sem autor. Desmascarando a Maçonaria francêsa. A Tribuna, Recife, 16 de maio de 1934, p. 3.

LEME, Dom Sebastião. Boa Imprensa. A tribuna, Recife, 04/07/1935, p.3.

Sem autor. MAÇONARIA e o Estado em Portugal. Boletim Mensal da Arquidiocese, Recife jan./fev.1935, p. 6.

Sem autor. A maçonaria e a luta anti-religiosa. Boletim Mensal da Arquidiocese, Recife jan./fev. 1935, p. 9. 


\section{Referências}

ANECCHINI, Mariana, POZUELO, Yván; RODRIGUES, Ana Maria T. Estudios de La masonería en América Latina y el Caribe siglos XIX y XX. Santa Rosa: IHESOLP Ediciones, 2020.

BARATA, Alexandre Mansur. Maçonaria, Sociabilidade Ilustrada e Independência do Brasil (17901822). 1. ed. São Paulo-Juiz de Fora: Annablume-EDUFJF-FAPESP, 2006.

BARRUEL, Augustin. Memoires pour servir a l'histoire du Jacobinisme, vol. 4. London: De l'Imprimerie Françoise, 1798.

BENIMELLI, J. A. Ferrer. El contubérnio Judeo-Masónico-Comunista. del Satanismo al escándalo de la P-2. Madri, Edições ISTMO, 1982.

CHARTIER, Roger. A História Cultural: entre práticas e representações. Trad. Maria Manuela Galhardo. Lisboa: DIFEL/ Rio de Janeiro: Bertrand Brasil, 1990.

GIRARDET, Raoul. Mitos e mitologias políticas. São Paulo: Cia das Letras, 1987.

GONÇALVES, Marcos. Missionários da 'boa imprensa': a revista Ave Maria e os desafios da imprensa católica nos primeiros anos do século XX. Revista Brasileira de História. São Paulo, v. 28, n. 55, p. 63-84, 2008.

LEFRANC, François. O Véo Levantado, ou o Maçonismo Desmascarado; isto he: o Ímpio e execrando systema dos Pedreiros-Livres conspirados contra a Religião Catholica, e contra o Throno dos Soberanos. Tradução do francês. Lisboa: Imp. Liberal, 1822-23.

MARIN, Jérri Roberto. Reflexões sobre a imprensa Católica no Brasil. Religião e Sociedade, Rio de Janeiro, v. 38, n. 3, p. 197-217, 2018.

NASCIMENTO, Luís do. História da Imprensa de Pernambuco. Recife: Imprensa Universitária, 1967. (Vol. 9).

ORTIZ, Renato (org.). Pierre Bourdieu. Trad. Paula Monteiro e Alicia Auzmendi. São Paulo: Ática, 1983.

OLIVEIRA, Carmem Lopes de. Entre Deus e o grande arquiteto do universo: relações conflituosas entre a igreja católica e a maçonaria em Pernambuco (final do século XIX início do XX). Dissertação de mestrado em História, Universidade Federal Rural de Pernambuco, 2017.

PEREIRA, Nilo. Conflitos entre a Igreja e o Estado. Recife, Editora Massangana,1982.

PEREIRA, Nilo. Dom Vital e a Questão Religiosa no Brasil. 2. ed. Rio de Janeiro, Tempo Brasileiro; Recife: Arquivo Público Jordão Emerenciano, 1986.

PESSOA, Fernando. As Origens e essência da Maçonaria. São Paulo: Landy Editora, 2006.

SILVA, Carlos André Moura da. Fé, Saber e Poder: os intelectuais entre a Restauração Católica e a política no Recife (1930-1937). Recife: Prefeitura da cidade do Recife, 2012.

SILVA, Augusto César Acioly Paz. "Maçonaria e República: confrontos, tensões e atuação sociopolítica de maçons em Pernambuco nas décadas de 1930 e 1940". Tese de Doutorado em História, Universidade Federal de Pernambuco, 2013.

SILVA, Augusto César Acioly Paz. Maçonaria em Pernambuco (1900-1930) lições para nossos dias. 2. ed. Maceió: Olyver, 2020.

SILVA, Giselda Brito. "A lógica da Suspeição contra a força do Sigma: discursos e polícia na 
repressão aos integralistas em Pernambuco". Tese de Doutorado em História, Universidade Federal de Pernambuco, 2002.

SILVA, Marcos José Diniz. Moderno espiritualismo e espaço público republicano: maçons, espiritas e teosofistas no Ceará. Tese de Doutorado em Sociologia, Universidade Federal do Ceará, 2009.

SILVA, Michel (org.). Maçonaria no Brasil: História, política e sociabilidade. Jundiaí: Paco, 2015.

SILVA, Silvia Cortez. Tempos de Casa-Grande: 1930-1940. São Paulo: Perspectiva: FAPESP, 2010.

SILVA, Severino Vicente. Da Guerra a Neocristandade: a Tribuna Religiosa 1917-1919. Curitiba: Prisma, 2014.

VIEIRA, Davi Gueiros. O Protestantismo, a Maçonaria e a Questão Religiosa no Brasil. Brasília: UNB, 1980.

\section{Nota de autoria}

Augusto César Acioly Paz Silva é doutor em História pela Universidade Federal de Pernambuco UFPE. Professor do Departamento de História do Centro de Ensino Superior de Arcoverde (CESA), ligado à Autarquia de Ensino Superior de Arcoverde (AESA). E-mail: cesar_historia@hotmail.com.

\section{Como citar esse artigo de acordo com as normas da revista}

SILVA, Augusto César Acioly Paz. A "boa imprensa católica" na divulgação das visões acusatórias sobre a maçonaria na década de 1930. Sæculum - Revista de História, v. 26, n. 44, p. 106-118, 2021.

\section{Contribuição de autoria}

Não se aplica.

\section{Financiamento}

Não se aplica.

\section{Consentimento de uso de imagem}

Não se aplica.

\section{Aprovação de comitê de ética em pesquisa}

Não se aplica.

\section{Licença de uso}

Este artigo está licenciado sob a Licença Creative Commons CC-BY. Com essa licença você pode compartilhar, adaptar, criar para qualquer fim, desde que atribua a autoria da obra.

\section{Histórico}

Recebido em 25/01/2021.

Modificações solicitadas em 11/05/2021.

Aprovado em 08/06/2021. 